\title{
Translation Maneuvering and Speech Stereotypes in Harold Pinter's Plays
}

\author{
Tatyana P. Tretyakova* \\ St. Petersburg State University \\ 11 Universitetskaya nab., St. Petersburg, 199034, Russia
}

Received 29.11.2014, received in revised form 02.12.2014, accepted 23.01.2015

\begin{abstract}
Harold Pinter (1930-2008), a Nobel Prize-winning English playwright (2005), one of the most influential modern British dramatists, still remains in many aspects an enigmatic figure for Russian spectators. The reasons for that lie in a complex exploration of human psyche and the inner world of the individual through very casual interaction full of with clichés and stereotypes that Pinter's characters use. There are a lot of interactive implications in his plays and they are delivered by the code and specific medial psychological and social format of the setting. It is argued that when translating Pinter's dialogue the translation scheme should rely on the functional concept of maneuvering that provides choice in selecting, meeting audience demand, and presentation devices in the target language. The study of expert translations of such common speech stereotypes as "you know" "I mean", "you see "in plays "The Caretaker" and "The Collection show pragmatic shifts between the source and target texts changing the effect of the dialogue.
\end{abstract}

Keywords: Harold Pinter, translation, speech stereotypes, concept of maneuvering, pragmatic meaning, medial space.

Research area: philology.

\section{Introduction}

Harold Pinter (1930-2008), a Nobel Prizewinner in Literature (2005) English playwright, screenwriter, director and actor is considered to be one of the most influential modern British dramatists. Although much has been written about Pinter he still remains a very controversial figure whose work gave impetus to a lot of critique on part of scholars, theatre critics and staging directors (www.haroldpinter.org) .

Much of the controversies lie within the interpretations which his creative work opens. His works were compared to absurdist and postmodern traditions, to Samuel Beckett, Eugene Ionesco as well as to the British tradition of the Angry Young men. It is Anton Pavlovich Chekhov who with his plays anticipated this form of drama which we find in Pinter's plays. Ronald Knowles wrote that "there is not a single dramatist of the twentieth century with whom Pinter has not been compared or contrasted" (Knowles 2009). Despite certain disagreement as to the placement of Pinter in the context of modern drama development trends his plays revealing the individual inner world, loneliness of people, misunderstandings existing between them are still very popular and much

(c) Siberian Federal University. All rights reserved

* Corresponding author E-mail address: tretyakova.tp.50@gmail.com, ttretyakova@eu.spb.ru 
appreciated by readers and spectators in the English-speaking countries.

However, it is not the case with the Russian public. There are few translations into Russian of 29 plays written by H. Pinter only 15 were translated into Russian. Although the first publication "The Caretaker" in Russian appeared in1968 it was only in 1988 that the first collection of Pinter's plays "The Caretaker and other plays" was published by the "Raduga" Publishing house. Nevertheless there always existed a challenging task to incorporate the British classic of English drama onto the Russian scene. At the end of the last century there have been made translations that were accepted by directors for staging Pinter in Russia. For example, "The Lover" translated by Viktor Denisov was staged by such directors as R.Viktyuk in Kiev (1998),by V.Mirzoyev(2002) and L.Georgievsky (2008) in St. Petersburg and by A.Serov (2012) in Volgograd. In 2014 Moscow theatre named after Evgeny Vakhtangov brought to Bremen H. Pinter's play "Betrayal" within the program La Saison Russe. Even this very short list shows the growing interest to Harold Pinter in Russia (see also Evans 2009). Nevertheless the effective translation of Pinter's play remains to be an extremely difficult task. The major reason is the following - although dialogues in Pinter's plays seem absurd the characters are not abstract and their speech is realistic, raising vital problems of human life. The palette of implications is diverse and often very sophisticated.

Each play has very few characters, dialogues are brisk and simple, however they provide a lot of interactive implicatures and often have humorous effect. This brings forth a special difficulty for translation and staging. The simplicity of the form is bound to the complexity of possible conclusions. Pinter's peculiarity lies in the exploration of the inner world of human psyche and sensibility. These topics are very close to Chekhov drama which is very popular in Britain. (see also: Knowels 2009: 74-76). The reasons for this lies not so much in the complex exploration of human psyche and the investigation of the inner world of the individual is all conducted through dialogues.

There is a strong compromise between the speech habits of characters and the theatrical effect. There is a specific way Pinter's characters talk with repetitions, hesitation pauses, silence all so typical for everyday speech. Moreover, it is a specific kind of realism that gives way to conversational linguists study Pinter's dialogues as a reflection of every-day speech. The valid interpretation of Pinter's dialogues lies in the comparative analysis of the code characters use and their conduct. The code and the conduct run the medial space in face-to-face communication. The medial format of the text incorporates three components - the code, the channel and rules of codification of the information (Tchernyavskaya 2013). All three aspects provide the alternatives for interpretations of the original drama as a source text in translation and performance. The medial format of the source text and the target text may have some differences and they may be effective in different ways.

The directors often use such multifaceted maneuvers in making the production of Pinter's play in a new format with the idea of introducing the author to the Russian public. This can be said about the production of "The Caretaker" by Yu. Boutusov in St. Petersburg (1998). A new way of performing, making narratives of dialogues led to inevitable transformations and distortions of the contents. As long as the form is a part of content of the discourse in the case of drama, the new interpretation appeared to have forged effect if compared to the original.

The aim of this paper is to introduce in translation analysis the concept of maneuvering strategy which allows on a linguistic level to 
identify pragmatic meanings of utterances with speech stereotypes in the original and in translation. The examples for the analysis were taken from "The Caretaker" ("The caretaker and other plays" London, 1962) and its Russian translation (“Сторож” и другие драмы. М.: Радуга 1988).

\section{The concept of maneuvering in translation analysis}

In order to work out a more relevant approach for the analysis of such complex text format as that of Pinter's translations we introduce the idea of the maneuvering triangle or strategic maneuvering triangle. This concept was first introduced for the evaluation of argumentation discourse (van Eemeren 2010). It is based on the assumption that there are indivisible speech acts which provide argumentation practice, but it is possible to distinguish several aspects that can help in providing a more "precise characterization of strategic function that the argumentation moves fulfil" (op.cit:93). The whole idea of strategic maneuvering is based on the discourse analysis of the dialogue from the vantage point of pragmadialectics that considers integrated approach to functional analysis.

Argumentation moves can be compared to dialogical moves. The analysis of dialogues without argumentative part of the content would preserve the dialectics of discourse. In this case each individual aspect can be taken into account and the evaluation of effective communication could be spotted by identifying in reconstruction direct and covert meanings. As long as the dialogue form of communication is a functionally complex form of interactions, we believe that functional semantics may be very helpful as a method of the analysis. By functional semantics we mean identifying the pragmatic effect of the utterances that can be identified through the context pragmatics. This approach allows to look for the integrated meaning of utterances consisting of the knowledge of situational conventions, $<$ addresantaddressee $>$ relations and rhetorical impact of the utterances. This approach proved to be efficient in pragmatic interpretation of texts which are remote from nowadays but which allowed to identify the possible intentional communicative meanings (Tretyakova, Tsvinaria 2012). The comparison of source and target texts could be carried "functional equivalence" which allows to identify the effect two texts produce (Nida 2003). As it has been shown in the introduction it is really difficult to reach the equivalence in translations of Pinter's plays as the styles of colloquial casual speech registers in source and target languages are so different. It is known that the most effective way to understand how to translate and identify the challenging issues is through the analysis of expert translations that have been accomplished.

Now let's turn to the maneuvering scheme. There are three aspects F. van Eemeren associates with three types of choices that are made in strategic maneuvering and these choices relate to different qualities of interpretations. First, there is a choice connected with the "topical potential". In case of the dialogue this is the topic under discussion which provides the structure of the mini-dialogue as a text unit. A variety of subtypes can be defined in terms of the situational propositional content with conversational maxims and commitment sets. Linguistic insights consider the differences between the source and target texts.

Second, there is the choice of how to adapt the moves to meet "audience demand" (op.cit.:94) . At this point we deviate from the argumentation theory because the procedural points in the discussion are not relevant. From the vantage point of translation theory the focus here lies in creating the acceptable content in target language that can be in agreement with the audience/ reading public, i.e. creating necessary 
adjustments for better understanding. Here the complications may appear with the audience as a heterogeneous phenomenon and the existence of universal and particular audience.

Third, there is the use of "presentational devices" which involves a choice of the best ways of reconstruction the pragmatic effect. The differences of the devices in this case are connected with the effective tools of language choice and presentational variations. In this case tropes, figures of speech, speech registers and all language phenomena used for creating cohesion in the text and highlighting special facets in the text.

Although the three aspects are discussed separately here we repeat that all of them are inseparable and were devised entirely for analytical purposes. But these three aspects give the translation studies scholar the ability to look for the strategic maneuvering of interpretations:

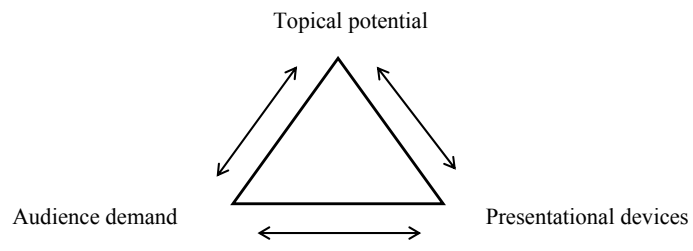

The integration of all these theoretically devised maneuvers allows using them in both analysis and evaluation of translation. In the analysis to follow we shall try to show in what way this theoretical concept is applicable in translation analysis of speech stereotypes in Pinter's play “ The caretaker”.

\section{On speech stereotypes}

Speech stereotypes make an open functional field used for quick and economical conducting the communication process the presentation. These ready-made communicative formulas provide the speaker with quick interactive tools. They work as discourse markers on one hand and as cumulative mini-discourse items modeling the communicative situation proper. They can be etiquette formulas of greetings, farewells, prescriptions, taking turns in the conversation etc. We can say that social categorization of clichés concerns stereotyping if social context is involved in description. Such a phrase as How are we today? may very be a greeting cliché in doctor - and patient - dialogue. There may be examples where $O K$ is not a marker of an agreement, but a part of closing sequence of the conversation: Okay. Bye-bye. In fact speech stereotypes provide the content of social categories. It is through stereotyping that we can identify individuals in terms of sex, ethnicity, social rank etc. as well as emotions, interests and abilities and so on. Here we would like to stress that the notion of speech stereotype understood as an umbrella term for all sorts of fixed expressions (or idioms) the functional meaning of which is condensed codification of pragmatic meaning of the utterance. Whenever the interpretation concerns behavioral and cultural aspects of communication these utterances can be interpreted as stereotypes. Then we focus on social patterns of communication.

Speech stereotypes belong to symbolic sphere of expression reflecting human behavioral habits. On one hand they are very compact code-types connected with the semiotics of interaction. On the other hand 'decodification' (or reconstruction) process implies long description of register, situational format, cultural specification and psychological implications. There are such issues in stereotyping which are mostly connected with the perception of social groups. They influence information processing about individuals in various ways mostly through identifying specific lexis and emphatic colloquial syntax and the use of clichés. The language seldom invents new elements but it often uses the old ones in a new environment. This involves discourse framework: 
legal dialogue, feministic quarrel, political debate etc.

When translating speech stereotypes the strategic maneuvering is dealing mostly with the presentational device phenomenon and to some extent to the audience demand. If we look at the classes of speech stereotypes as codes, then we may use the classification of semiotic code types. The major groups would be stereotypes used for appraising, prescription and formatting verbal interaction. The latter group is connected with speech etiquette, phatic communication, and meta-lingual utterances. This group includes such stereotypes as I see, I mean, you know, all right. They provide a special attuning to the conversation and in Russian the same meaning is revealed with such items as ладно, видишь ли, ну, да. These phrases provided connections, intrusions and interruptions and it is the situation that arranges the choice of strategic maneuvering putting the speech stereotype in a correct slot of communicative moves. These moves are connected with the connection, intrusion or interruption. These speech stereotypes are most characteristic of the natural speech effect that Pinter's plays produce on the public. In this approach we follow the opinion that the twentieth century drama dialogues in many ways reveal the ordinary talk with repetitions, interruptions, stammering and hesitation with unfinished clauses (Mandala 2007).

\section{Approaching the strategic maneuvering in translation}

When dealing with the speech stereotypes in The Caretaker we are bound to delve into the scheme of interaction between characters. There are three characters - Mick, Aston and Davies. Mick and Aston are brothers. The two brothers seem to live there periodically and they do not take any care of place. Aston brings Davies an old man, leading a depressed, lonesome life. Both brothers periodically engage Davis to take care of their house. The three characters make a triangle of solitaries. Their interaction takes place in a claustrophobic filled with useless junk.

Here is an example of the dialogue about Davies's papers which were left at Sidcups :

ASTON. (a)What are they[papers] doing in Sidcups? DAVIES. (b)A man I know has got them. I left them with him. You see? (c)They prove who I am. You see! (d) I am stuck without them.

ASTON. (e)What's that?

DAVIES. (f) You see, what it is, you see I changed my name! Years ago...I got an insurance card here. (He takes a card from his pocket) (g) Under the name of Jenkins. See? Bernard Jenkins. Look. (The Caretaker,20)

In this dialogue the stereotype stereotype you see is used to attract the attention to a new topic under discussion. Davies is not sure if that new information has really been interesting for Aston and that he was correctly understood ((c) (d)). The repetition of the same phrase (f) is the realization of commitment to prove the importance of words, so that the Aston believes him. One more argument showing the importance of the topic is the delivery of the card as an additional evidence ( $\mathrm{g}$ ).

АСТОН. . (а) А что им делать в Сидкапе?

ДЭВИС.. (б) Они у одного типа, моего знакомого. Я их у него оставил. Понимаешь? (в) Там прописано, кто я. Я без них, без бумаг ходить не могу. Оттуда видно, кто я такой (г) .Понял? Я без них никуда.

АСТОН. (д) Почему ж так?

ДЭВИС. (е) Понимаешь, дело в чем... понимаешь, я имя сменил. Давно уже...У меня тут страховая карта есть (ж) (Вынимает карту из кармана) На 
имя Дженкинза. Видишь? Бернарда Дженкинза (Сторож 30-31).

Source and target texts compared the following strategic choices in respective maneuvers. On the whole the Topical potential is more or less achieved in terms of the semantic nomination. However, the translation of the card as “страховая карта" sounds strange in Russian. We call this type of document “удостоверение". As far as the presentational strategy is concerned we can find a number of discrepancies. Thus, the stereotype phrase in the source text has the phatic meaning of drawing attention to something, whereas in the target text there is a bigger interval between the utterances ((в), (г)) than between ((c) (d)). The phatic functional meaning gets a different attuning.The tension of the dialogical move is compensated by the repetition " $Я$ без них, без бумаг ходить не могу". This repetition creates anxiety although the pragmatic vector is different. Thus the strategy of presentation choice provides differences in attuning of source and target texts.

One more example can illustrate the interaction of Aston and Davis with stereotypes I mean, you know. These utterances when used in an informal and casual speech may express opinion or advice, contradiction or correction. Both of them mark the keeping of interactive initiative of the speaker.

DAVIES.(a) Well... I never done caretaking before, you know...(b)I mean to say... I never... what I mean to say... (c) I never been a caretaker before. (Pause) . ASTON. (d) How do you feel about being one, then? DAVIES. (e) Well, I reckon... Well, I'd have to know... you know...

ASTON.(f) What sort of ...

DAVIES. (g) What sort of ... you know...

(The Caretaker,42)
In this example Pinter shows Davies' psychological problems, he can't give the direct answer. There are a lot of repetitions of such function items as well, sort of. The whole extract produces the example of neurotic anxiety. The stereotype you know ((a) (e)) together with well show the inability to give an opinion. The same is in $(\mathrm{g})$. Davies tries hard to introduce some argument in his speech but he is unable to finish the phrase. Speech stereotypes (b) - I mean to say $<$... what I mean to say accompany explanation and argumentation. But instead of taking the speech initiative Davies fails to introduce any reasonable argument. His speech manner is close to psychic patients. With that sort of repetitions and abrupt utterances one can draw some patterns of human thinking. Repetitions of function phrase without the development of topical potential the vision of disturbance in psychological status of the character. Let us turn to the translation strategies

ДЭВИС.(а) Видишь ли, я никогда не сторожил раньше понимаешь... (б) я ведь ...я никогда... я что хочу сказать... (в) я никогда сторожем не был (Пауза).

АСТОН. (г) А как насчет того, чтобы стать им? ДЭВИС. (д) Ну, как сказать... Ну мне бы надо знать... понимаешь...

АСТОН.(е) Какие ...

ДЭВИС. (ж) Да, какие ...nонимаешь... (Пауза) (Сторож, 48)

The stereotype phrase you know is translated by “понимаешь” ((а) (д) (ж)) that has different functional semantics. More close to the original phrase would be variant "понимаешь ли" or in many cases the communicative semantics of Russian phrases“ну” "ну...это”, “ как это сказать”. Here the representation potential in target text should be more socially and psychologically biased. Davies is the character 
who suffers from isolation. His poor socializing shows that he is an alien tramp having all sorts of phobia.

There is no equivalence in the expression of tension in the interaction of characters. There should be presentational variation in strategic maneuvering. The tension of the dialogue in the target text might be achieved by transgressing boundaries of presentational potential and incorporating speech patterns which are typical for the low middle-class people and some Russian colloquialisms. The translation of "I mean" by the Russian "типа"

This would respond to the third component of strategic maneuvering, i.e. audience demand. The adjustment to the audience demand would give way to the creation of a more dynamic way of translation that should be effective in the creation of tension and anxiety in the dialogue. The audience demand is close to the functional equivalence, although the channel and the code are different. The audience shouldn't be the passive consumer of "plain" equivalents of speech stereotypes.

\section{Conclusion}

At present we witness a growing interest in the creative work of Harold Pinter in Russia. New productions of his plays appear and there is a demand in creating new translations. His legacy is diverse, very interesting and controversial. and the public is waiting for learning more about this author.

The concept of the strategic maneuvering applied to the translation helps to analyze and evaluate the source and target texts as functional phenomena. The cohesion associated with the topical meaning as well as presentation devices and audience demand allow to take a differentiated view at the process of translation The three aspects which in reality exist inseparably could be applied to translation analysis thus permitting a more sophisticated analysis and evaluation of Pinter's plays.

\section{References}

1. Chernyavsraya, V.Ye. Text in a medial space.[Tekst v medial'nom prostranstve: uchebnoye posobiye] M.: Knizhnii Dom “Librokom”, 2013, 232 p.

2. Frans H. van Eemeren. Strategic maneuvering in argumentative discourse: extending the pragma-dialectical theory of argumentation. John Benjamins Publishing Company. Amstredam, Philadelpia 2010, $308 \mathrm{p}$.

3. Evans, Charles, Pinter in Russia // The Cambridge Companion to Harold Pinter / Ed. by Peter Raby. Second Edition. Cambridge: Cambridge University Press, 2009, p. 155-174.

4. Knowels, Ronald. Pinter and twentieth-century drama// The Cambridge Companion to Harold Pinter / Ed. by Peter Raby. Second Edition. Cambridge: Cambridge University Press, 2009, p. 74-87.

5. Mandala, Susan.Twentieth-Century Drama Dialogue as Ordinary Talk: Speaking Between the Lines. Ashgate. Cornwall. 2007. 152 p.

6. Nida, Eugene A. \& Taber, Charles R. The Theory and Practice of Translation. Brill Academic Publishers, 2003. 218 p.

7. Tretyakova, Tatyana P. Choice factor of communicative semantics in speech cliché translations (by the examples of A.P. Chekhov and H. Pinter) [Faktor vybora kommunikativnoy semantiki v perevode rechevykh klishe (na primere perevodov A.P.Chekhova i G.Pintera \ Universitetskoye perevodovedeniye .Vip.11: materialy XI Mezdunzrodnoy nauchnoy koferentsii po perevodovedeniiu 
"Fedorovskiye Chteniia" 20-23 oktiabria 2010.] Proc.11 th International Conference "Fedorov Readings". Saint-Petersburg, 2011, p. 483-490.

8. Tretyakova, Tatyana., Tsvinaria, Marina. Context pragmatics of samples of social discourse in Beowulf / Ex Philologia Lux: Essays in Honour of Leena Kahlas-Tarkka (Mémoires de la Société Néophilologique de Helsinki XC), ed. by Jukka Tyrkkö, Olga Timofeeva \& Maria Salenius. Helsinki: Société Néophilologique, p. 241-260

\title{
Переводческое маневрирование: речевые стереотипы в пьесах Гарольда Пинтера
}

Т.П. Третьякова

Санкт-Петербургский государственный университет Санкт-Петербург, 199034, Университетская наб., 11

\begin{abstract}
Гарольд Пинтер (1930-2008), лауреат Нобелевской премии по литературе за 2005 год и один из наиболее влиятельных современных драматургов, все еще остается во многом загадочной фигурой у российских зрителей. Причина этого кроется в том, что сложности человеческой психики и внутренний мир человека представлен в его пьесах в диалогах, отражаюших обыденное общение, сотканное во многом из речевых клише и стереотипов. В репликах героев много скрытых смыслов, которые передаются с помощью стереотипных кодов и особого психологического и сочиального формата ситуачии общения. В статье представлена гипотеза о том, что перевод диалогов Г. Пинтера требует особой переводческой функииональной схемы, связанной с концепцией стратегий маневрирования, с выбором тематического варианта, требований аудитории и лингвистических приемов реализации в переводном тексте. На примере таких распространенных речевых стереотипов, как "уои know" "I mеan", "уои sее” и их переводах, встречающихся в пьесах "Сторож" и "Коллекция", показана специфичность когнитивной тональности диалога. В анализе отмечаются некоторые прагматические сдвиги, возникающие при переводе, изменяющие воздействуюшую силу диалога.
\end{abstract}

Ключевые слова: Гарольд Пинтер, перевод, речевые стереотипы, стратегии маневрирования, прагматическое значение, диалогический текст.

Научная специальность: 10.00.00 - филологические науки. 